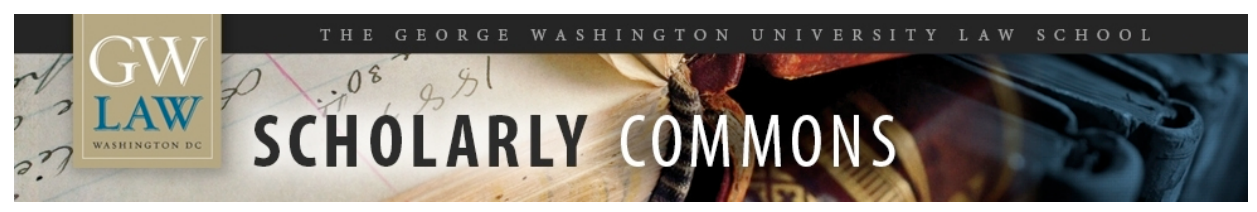

\title{
Kagan's Atlantic Crossing: Adversarial Legalism, Eurolegalism, And Cooperative Legalism
}

\author{
Francesca Bignami \\ George Washington University Law School, fbignami@law.gwu.edu \\ R. Daniel Kelemen \\ Rutgers University - Newark
}

Follow this and additional works at: https://scholarship.law.gwu.edu/faculty_publications

Part of the Law Commons

\section{Recommended Citation}

Bignami, Francesca, Kagan's Atlantic Crossing: Adversarial Legalism, Eurolegalism, And Cooperative Legalism (2017). Francesca Bignami and R. Daniel Kelemen, Kagan's Atlantic Crossing: Adversarial Legalism, Eurolegalism, and Cooperative Legalism in European Regulatory Style, in Varieties of Legal Order: The Politics of Adversarial and Bureaucratic Legalism (Jeb Barnes \& Thomas F. Burke eds., Routledge, 2017); GWU Law School Public Law Research Paper No. 2017-66; GWU Legal Studies Research Paper No. 2017-66. Available at SSRN: http://ssrn.com/abstract=3043768

This Article is brought to you for free and open access by the Faculty Scholarship at Scholarly Commons. It has been accepted for inclusion in GW Law Faculty Publications \& Other Works by an authorized administrator of Scholarly Commons. For more information, please contact spagel@law.gwu.edu. 


\title{
Kagan's Atlantic Crossing: Adversarial legalism, Eurolegalism and
}

\section{Cooperative Legalism in European Regulatory Style}

\author{
Francesca Bignami and R. Daniel Kelemen
}

Robert Kagan is known primarily as a scholar of American public law, but Kagan's studies of America have always been informed by a comparative perspective. Though many scholars and pundits speak of 'American exceptionalism,' Kagan is one of the rare few who understands that the truly exceptional features of American politics and law can only be recognized on the basis of detailed study of other polities. Early on, Kagan saw that to succeed as an Americanist, he must also become a comparativist. He has done so with such success that his work on comparative law and regulation not only has contributed to his insights on the US, it also has made landmark contributions to the study of law and regulation across Europe and Asia. ${ }^{1}$

In this chapter we focus on one particular contribution Kagan has made to the study of law and politics in the European Union, namely in stimulating a debate over the potential spread of “adversarial legalism' to Europe. In the mid- to late 1990s, Kagan was in the midst of producing a series of papers that would culminate in his path-breaking 2001 book, Adversarial legalism: The

\footnotetext{
${ }^{1}$ Though our chapter focuses exclusively on the debates Kagan has inspired concerning EU law and regulation, his work has also inspired similar debates about legal developments in Asia countries (See for instance Kelemen and Sibbitt 2002, Johnson 2003, Nelken 2003, Ginsburg 2008, Baharvar 2006-7).
} 
American Way of Law. In this work, he developed a concept, 'adversarial legalism,' that captured the distinctive features of American legal and regulatory style and he explained the origins and persistence of that style. As part of his research, he engaged in comparative studies of regulation in European countries, highlighting the advantages many enjoyed as compared to the US in terms of being more cooperative and informal and avoiding protracted and expensive legal battles. While highlighting these differences, however, he recognized some pressures for movement toward American-style regulation in Europe. This led him to question whether it was likely that Americanstyle adversarial legalism - with all the costly pathologies that accompany it - might take root in Europe. As Kagan (1997) put it succinctly in the title of a 1997 paper, "Should Europe worry about adversarial legalism?”

Kagan answered the question in the negative, emphasizing that entrenched legal institutions and cultures would prevent adversarial legalism from taking root in Europe. Some years later, R. Daniel Kelemen picked up on Kagan's question, but reached the conclusion that a legal style akin to adversarial legalism - one which he eventually termed Eurolegalism - was in fact spreading across the European Union (Kelemen and Sibbitt 2004; Kelemen 2006, 2011, 2012, 2013). In a 2007 paper, Kagan responded, challenging Kelemen's arguments by further developing the arguments presented in his 1997 "Should Europe Worry About Adversarial Legalism?" paper, again emphasizing that a number of 'entrenched differences' would prevent the spread of adversarial legalism in Europe (Kagan 2007). In a 2011 paper, Francesca Bignami extended the debate in a new direction, drawing on a case study of the data privacy field to suggest that EU regulation may be characterized by a pattern of cooperative legalism rather than adversarial legalism (Bignami 2011). Together, such contributions have given rise to a lively debate, with a number of other scholars adding empirical studies and theoretical arguments concerning the impact 
of the EU on national regulatory styles and exploring whether or not, or in which respects and to what extent, aspects of adversarial legalism may be spreading to Europe (See for instance, Bignami 2011, Cioffi 2009, Mabbett 2011, Meyerstein 2013, Rehder, 2009, van Waarden 2009). This debate has helped build analytic bridges across the Atlantic, enabling scholars of the US and Europe to compare trends in regulation in both contexts.

In this chapter we summarize this debate, highlighting the enduring importance of Kagan's conceptual contribution to the study of regulation in Europe. We begin by summarizing Kagan's main arguments about regulatory style in Europe and why US style-adversarial legalism was unlikely to take root in Europe. We then engage in a dialogue, presenting both Kelemen's argument that European integration is encouraging the spread of a variant of adversarial legalism"Eurolegalism"--and Bignami’s argument that distinctive features of national regulatory regimes prevent the spread of adversarial legalism in Europe and instead lead to the spread of an alternative pattern of "cooperative legalism". We then conclude by linking the discussion of our own work with other important contributions to the debate on regulation in Europe inspired by Kagan's work.

\section{Kagan on Why Europe Shouldn't Worry About Adversarial Legalism}

Kagan famously labeled the distinctive American legal style as “adversarial legalism.” He framed the exceptionalism of the American "way of law" by comparison with legal styles in European countries and other advanced industrialized countries. He captured some central elements of the distinction between adversarial legalism and European legal styles in the following passage that is worth quoting at length: 
"Viewed in relation to Western European governments (including the UK), the USA has developed a distinctive "legal style" - by which I mean its way of making, crafting, and implementing laws and regulations, conducting litigation, adjudicating disputes, and using courts. American laws generally are more detailed, complicated, and prescriptive. American methods of litigating and adjudicating legal disputes are more adversarial and costly. Legalistic enforcement is much more prevalent in American regulatory programs. American judges generally are bolder in scrutinizing and reversing governmental plans, regulations, practices, and decisions. Interest groups in the USA, consequently, more often use courts as an alternative political forum for seeking policy goals." (Kagan 2007, pp. 102-103).

In comparison to this distinctive American legal style, the legal styles that prevailed across European jurisdictions, while each distinct in many respects, tended to be more informal, cooperative, and opaque and less reliant on lawyers, courts, and private enforcement actions. Kagan recognized in his 1997 article that there were new pressures that might encourage adversarial legalism in Europe including international economic competition, competition in legal services, privatization and deregulation, growing political mistrust of government power, the 'federalization' of regulation in the EU, and political gridlock (Kagan 1997, pp. 171-179). Despite the existence of such pressures, however, Kagan concluded in his 1997 article and subsequent work that entrenched institutions and legal cultures in EU member states would discourage the spread of adversarial legalism to European countries (Kagan 1997, 2007). Moreover, he noted that the very fact that the pathologies of American style adversarial legalism were well known to Europeans would make them vigilant against the rise of that mode of regulation in Europe. As he 
put it in his 2007 article, "Globalization and legal change: The "Americanization" of European Law?", six entrenched differences distinguishing the US legal system from its European counterparts would ensure that the latter would not experience 'Americanization' of their legal systems. Specifically, he highlighted 1) the political nature and remedial powers of American judiciaries, 2) the pervasiveness of adversarial legalism in the regulatory process, 3) the hyperactive American tort law system, 4) the more limited rights to social provision in the USA, 5) the less demanding American tax laws, and 6) the punitiveness and adversarial legalism in American criminal justice as crucial enduring differences.

Kagan's foray into the study of European legal styles was seminal in that it has stimulated a lively debate about whether, and if so why, legal styles in European countries may be shifting toward something akin to adversarial legalism. Next each of us presents our own arguments on this question.

\section{Kelemen on Eurolegalism}

In a series of articles (Kelemen and Sibbitt 2004, Kelemen 2006, 2008, 2012) and in my 2011 book Eurolegalism: The Transformation of Law and Regulation in the European Union, I argue that the process of European integration is transforming traditional patterns of law and regulation across EU Member States and pushing them towards a European variant of adversarial legalism, which I term Eurolegalism. ${ }^{2}$ I argue that European integration is promoting the spread of Eurolegalism through two linked causal mechanisms, one economic and one political.

The first mechanism involves the process of deregulation and juridical reregulation linked to the creation of the EU's single market. As the EU pursued its 1992 single market project,

\footnotetext{
${ }^{2}$ In fact, the very term Eurolegalism was suggested to me by Professor Kagan. I remain deeply grateful for this catchy suggestion.
} 
traditional, informal national styles of regulation based on closed, insider networks and trust that had prevailed in European countries came to be seen as barriers to market integration. They were dismantled in field after field, sometimes as a result of EU policy initiatives that demanded liberalization and sometimes as the result of European Court of Justice (ECJ) judgments that ruled national regulations to be illegal non-tariff barriers to trade in the single market. But the EU did not stop with deregulation. In order to pursue their policy objectives, EU policy makers also sought to reregulate, to replace problematic national regulatory regimes with pan-European regimes compatible with the functioning of the Single Market. But the new EU regulatory regimes did not resemble traditional European styles of informal, cooperative regulation. Facing a greater volume and diversity of actors in the liberalized market and demands for a level playing field, EU lawmakers rely on regulatory frameworks that are more formal, inflexible, and judicialized. In short, the EU followed a pattern established in other polities whereby the creation of 'freer markets' actually requires 'more rules' and where deregulation is followed by 'juridical reregulation' (S. Vogel 1996).

The second causal mechanism stems from the political fragmentation that characterizes the EU's institutional framework. When EU policy-makers 'reregulate' at the European level, they do so within an institutional structure that generates political incentives to rely on a judicialized mode of governance. Political power in the EU is highly fragmented - divided horizontally between the Commission, Council and Parliament - and vertically between the EU and member state administrations. The fragmentation of political power in the EU generates principal-agent problems and breeds distrust between law-makers and the national administrations that implement most EU policy. The EU also has extremely weak administrative capacity, but does have a relatively strong judicial system under the leadership of the ECJ. This combination of political 
fragmentation, weak administrative capacity and effective judicial institutions encourages policymakers to enact laws with justiciable provisions and to encourage the Commission and private litigants to enforce them before European and national courts. In other words, EU policy makers seek to harness national and European courts and private litigants to help make up for their lack of central administrative capacity. This decentralized enforcement, backed by enforcement actions taken by the Commission before European Courts, helps to safeguard the implementation of EU policies across the large and fragmented European polity.

I recognize Kagan's (2007) point that a number of institutions entrenched at the national level in EU states continue to discourage adversarial legalism. He highlights the absence of jury trials, contingency fees, and massive damage awards in European systems of tort law, lower degree of politicization of European judiciaries, and the existence across Europe of more generous public social and medical services as examples of entrenched institutions that will discourage the rise of adversarial legalism in Europe. Consider for instance the fact that decentralized, private enforcement of legal norms is an important aspect of adversarial legalism. As Kagan rightly emphasizes, many rules of civil procedure in national legal systems across Europe discourage private enforcement. For example, the absence of contingency fee arrangements and Americanstyle opt-out class actions in most European jurisdictions raises the cost of litigation, while the absence of remedies such as punitive damage awards often reduces the potential rewards of successful litigation. The fact that many potential litigants across the EU face higher costs and lower potential awards discourages them from seeking to enforce their rights under EU law in court.

However, while such impediments continue to channel and constrain the spread of adversarial legalism, they do not block it entirely. A number of the traditional impediments to 
adversarial legalism in Europe - such as entrenched rules of civil procedure or patterns of organization in the legal profession - are themselves eroding under pressures generated by European integration. Having introduced a voluminous body of EU law - the so-called acquis communautaire - that establishes a wide range of rights and other legally enforceable norms, the EU now increasingly emphasizes that European citizens and other legal persons (ie firms) must enjoy better access to justice such that they can enforce these rights. To this end, the EU is leading a multi-pronged effort to create a "Genuine European Area of Justice" - improving access to justice and promoting the harmonization of procedural laws across the EU so as to facilitate private enforcement (Kelemen 2011, p. 58, Hartnell 2002, Hodges 2007). EU initiatives and related legal developments in this field have affected various aspects of litigation financing (eg legal aid, conditional fee arrangements and third party litigation financing) and procedures governing collective (group) litigation. ${ }^{3}$ Taken together these measures are inducing a change in the litigation landscape across Europe that is facilitating the spread of Eurolegalism.

Moreover, my argument that European integration is encouraging the spread of a mode of governance - Eurolegalism - that involves greater reliance on formal law, lawyers, and litigation, does not suggest that EU governance is identical to American-style adversarial legalism. I am not arguing that Eurolegalism mimics American adversarial legalism in all respects or that it has already seeped into every nook and cranny of law and regulation across all EU member states. Rather, to paraphrase Lord Denning famous description of EU treaty law, ${ }^{4} \mathrm{I}$ am arguing that Eurolegalism is an incoming tide. It flows into the estuaries and up the rivers. It cannot be held back, and it is transforming governance across a wide range of policy areas. As a result of the sort

\footnotetext{
${ }^{3}$ Traditionally, because American style contingency fees have been prohibited in European jurisdictions, litigants were discouraged by the potentially high costs of litigation. However, a number of recent developments have established new funding schemes for litigation that reduce the costs to plaintiffs. (See Kelemen 2011, pp. 58, 2013).

${ }^{4}$ See HP Bulmer Ltd v J Bollinger SA [1974] Ch 401 at 418.
} 
of institutional impediments Kagan identifies, the European variant of adversarial legalism Eurolegalism - is and will likely remain more restrained and sedate than the American version and will affect some policy areas and some member states less than others. Despite the reforms mentioned above, persistent differences between civil procedures in the US and EU mean that we will not see the sort of lawyer-driven, contingency-fee financed, class actions in Europe that are so common in the US in fields ranging from securities law to product liability. And the increases in private enforcement we are seeing in Europe will vary significantly across policy area, with private parties more quick to take up new opportunities to assert their EU rights in court in fields such as securities and antitrust (where potential litigants tend to be well resourced corporations or investors) than in the field of disability rights (where potential litigants tend to be workers of modest means who have been victims of discrimination).

But such variations across policy areas and across jurisdictions do not take away from the broader point that Eurolegalism is spreading. And the fact that Eurolegalism is not synonymous with American adversarial legalism does not take away from the point that legal style in the EU is shifting in an American direction. In my 2011 book (Kelemen 2011) documenting the EU's influence on the spread of Eurolegalism, I take the mid-1980s as a baseline for all quantitative measures and case studies and assessing shifts in regulatory style from traditional European forms toward Eurolegalism over the next two decades. I highlight cross-cutting indicators of the shift in legal style including aggregate data on legal activity, such as litigation rates, spending on legal services and legal expenses insurance. I also look at qualitative changes in the civil and administrative procedures, such as the spread of class action lawsuits and conditional fee arrangements, which reflect and contribute to the spread of Eurolegalism. Finally, I also conduct case studies of particular policy areas in which I trace shifts in legal style toward Eurolegalism in 
securities regulation, competition law and disability rights both at the EU level and in the UK, France, Germany and the Netherlands. In these case studies, I use process tracing to demonstrate that legal and regulatory styles in Europe in these fields have shifted from traditional styles of regulation towards Eurolegalism, and to demonstrate that the causal mechanisms behind these shifts are those anticipated by my theory.

\section{Bignami on Cooperative Legalism}

Turning to the argument that, paraphrasing Kagan, Europeans shouldn't worry about adversarial legalism, this section presents evidence from my own research and that of others that support a different pattern of regulatory change-what I call cooperative legalism. The reason, I suggest below, for this somewhat surprising outcome is to be found in the operation of the two causal mechanisms outlined above: the theorization of market liberalization and political fragmentation in Kagan and Kelemen is heavily influenced by the distinctive American experience with these two phenomena and, as it turns out, when transposed to a different political and institutional context, they produce quite different outcomes, most significantly a less prominent role for courts in regulatory policymaking.

To understand the nature of regulatory change in the Europe, it is helpful to unpack the category of adversarial legalism into the two dimensions identified in Kagan's original typology of modes of policy implementation and dispute resolution. The first dimension captures the extent to which decisions are driven by horizontally situated parties (participatory) or hierarchically superior officialdom (hierarchical). The second captures the degree to which government decisions are based on the rigid application of a dense set of legal rules and sanctions (formal) or 
the discretionary exercise of loosely defined authority (informal). Policy implementation in the United States is classified as "adversarial legalism" because it generally is party-driven in the context of an extensive, formal set of rules and procedures that generate considerable litigation.

In my study of EU data privacy regulation from the mid-1970s to 2010, I find evidence of adversarial legalism across the four country cases (UK, Italy, France, Germany) only on the formality dimension and not on the party-driven dimension. In all four countries, the law was reworked to contain more extensive investigatory and sanctioning powers and these powers were being used by data privacy regulators, in particular in France and Italy, suggesting a move, as Kagan had predicted, from an informal and consensual style of regulatory enforcement to a more legalistic and punitive approach. On the party-driven dimension, I find a trend toward more party participation, but through self-regulation, not rights-driven contestation and litigation as in the US. Self-regulation represents continuity for the UK and Germany, systems known for certain neocorporatist practices, but signifies a shift for France and Italy which have a reputation for top-down administration with little role for interest groups. Neo-corporatism involves a significant role for representative interest associations in policy implementation, either alone or in tripartite settings generally composed of labor, industry, and government representatives. Self-regulation, which entails the exercise of regulatory powers by market actors, can be undertaken by the same industry and professional associations that are central to neo-corporatism. Even in those instances in which self-regulation is undertaken by different types of market actors, such as individual firms, the division of public-private power resonates with neo-corporatist institutional arrangements. Although Kagan does not address directly self-regulation, adversarial legalism's formality dimension of detailed rules and little administrative discretion, together with its rights-driven model of public participation, suggest that there is little room for the flexible and context-sensitive 
approaches to implementation that self-regulation is designed to foster. Because of this pattern of continuity (i.e. little litigation) and change (i.e. more legalistic rule enforcement and more selfregulation in certain member states) in the data privacy case, I conclude that European regulatory systems are converging on a style of "cooperative legalism."

The data privacy case, as well as some of the other empirical work reviewed below (Bellantuono 2014, Cioffi 2009, Bastings, Mastenbroek and Versluis 2014, Van Cleynenbreugel 2014, Hodges 2014, Van Waarden and Hildebrand 2009), point to three difficulties with the theoretical framework of adversarial legalism and suggest ways of refining our understanding of the ongoing phenomenon of shifting regulatory styles in Europe. As described earlier, the adversarial legalism hypothesis is premised on the causal factors of market liberalization and political fragmentation. What these studies suggest, however, is that the logic of these causal factors operates differently in the American and European contexts and therefore some of what is believed to be universal to the phenomena of market liberalization and political fragmentation, in particular adversarial litigation, may be particular to the American historical experience.

The first difficulty with the adversarial legalism hypothesis concerns the market liberalization prong. In his original piece, Kagan suggested that more rules give rise to more legal fights about the rules inside administration and in the courts (Kagan 1997, pp. 173 175). However, both his comparative typology of modes of policy implementation, which includes the classic Weberian category of bureaucratic legalism, as well as some of the evidence from the European experience with market liberalization, suggest that there is an alternative way of governing with a dense body of rules - bureaucratic administration of rules by government authorities. For market liberalization to work and for the normative commitments of the rule of law to be met, the rules must be transparent and be subject to oversight by an independent judicial body but they do not 
necessarily have to be crafted through a long and drawn-out process of adversarial contestation. This, as I briefly review below, is the form of regulatory governance that appears to be taking hold in a number of sectors in the EU.

Similar to the data privacy sector, many of the regulatory schemes introduced with market liberalization and re-regulation involve a central role for a newly created (or newly empowered) national regulatory authority endowed with extensive policymaking and enforcement powers: competition authorities (Maher 2000), telecommunications authorities (Thatcher 2007), energy authorities (Thatcher 2007, pp. 209-230, Bellantuono 2014, pp.16-17), financial services authorities (Thatcher 2007, pp. 90-118, Cioffi 2009, pp. 248), and environmental authorities (Bastings et al. 2014, p. 14) among others. Although it is difficult to obtain systematic comparative data on how these new enforcement powers are being used, anecdotal evidence suggests that, as in the privacy field, they are indeed being deployed by regulators, producing a more formal and punitive style of regulatory enforcement (See, e.g., Michel Faur et al., 2008, Bastings et al., 2014). To date, however, there is little evidence that these new regulatory powers have been accompanied by more contestation by the parties and their lawyers in administrative agencies and the courts. ${ }^{5}$ It is true that because regulatory authorities now have the power to impose significant administrative sanctions, including heavy fines, they have also had to afford regulated parties due process rights in the administrative process and their decisions have been subject to challenge in the courts (Van Cleynenbreugel 2014, pp.11-21). But this development should be seen as part and parcel of the transfer of sanctioning powers from the criminal justice system — which in many jurisdictions previously had the exclusive power to impose fines and other

\footnotetext{
${ }^{5}$ One exception appears to be certain areas of land-use planning and environmental regulation, where the Aarhus requirement of affording participation in the preparation of environmental impact statements has given rise to the right to participate in and challenge certain types of agency policymaking (See Nadal 2008).
} 
types of sanctions for regulatory offenses and which obviously had a highly developed set of guarantees for defendants - to administrative agencies, which are capable of pursuing regulatory offenses in a more single-minded fashion but in many cases do not possess a developed procedural framework. It does not appear that this proceduralization of enforcement has spread to the rest of agency policymaking and rulemaking activities. For instance, financial markets regulators have been under significant pressure from constitutional and administrative courts to improve the rights available to individual firms in the course of their investigations and enforcement proceedings ${ }^{6}$ but their policymaking activities, which often do involve public consultations, are not bound by strict procedural rules. This stands in stark contrast with the regulations issued by the U.S. Securities and Exchange Commission which are formulated through the adversarial American rulemaking process and are subject to intense and often unpredictable judicial review in the courts. ${ }^{7}$

The second difficulty with the original theoretical framework relates to the causal factor of political structure and the analogy that has been drawn between the EU political system and US federalism. Kagan argued that one of the causes of adversarial legalism in the US was the mismatch between a highly ambitious federal policy agenda and an underdeveloped federal administrative state, which led lawmakers to rely extensively on state and local authorities for implementation, and to write legislation giving litigants the right to go to court, both to monitor and challenge state implementation and to independently enforce federal policy in court. Kagan, as later developed by Kelemen, speculated that since the EU was also marked by a lack of federal

\footnotetext{
${ }^{6}$ See, for example, Grandes Stevens et al. v. Italy, nos. 18640/10, 18647/10, 18663/10, 18668/10, 18698/1, European Court of Human Rights, July 7, 2014.

${ }^{7}$ See, for example, Business Roundtable v. SEC, 647 F.3d 1144 (D.C. Cir. 2011).
} 
administrative capacity and the fragmentation of state power, EU lawmakers would write similar legal rights into EU law (Kagan 1997, pp.177-78).

The weakness of the argument is that it mischaracterizes to some extent the nature of the EU lawmaking process. EU lawmaking is called "harmonization" for a reason. When the EU enters a new policy area it does not regulate from tabula rasa but rather operates in the context of a thick regulatory field, which generally contains a number of highly developed national administrative and legal schemes. In contrast with US lawmaking, which is controlled by elected politicians who write legislation, including the rights-conferring legislation described by Kagan, to produce certain kinds of policies and therefore win votes (Epstein and O'Halloran 1999), the EU legislative process is structured to include a wide array of actors and incentives. One set of actors that does not have a US equivalent are the national governments represented in the Council, which are at least partially motivated by the desire to preserve their existing national schemesand regulatory styles — by uploading them into EU legislation (Börzel 2002). The older and more powerful member states, like France and Germany, which generally have both policy experience and bargaining clout, are very often able to do so. Following this logic, member states should have little incentive to support a foreign regulatory style in harmonization instruments and can be expected to oppose attempts to introduce elements of adversarial legalism by other legislative actors, most notably the Commission, which may very well be driven by the same enforcement incentives as US legislators. To the extent the member states seek to control national administrations and overcome the principal-agent problem identified by Kelemen in the previous section, they can use tools that are more congenial to their traditional regulatory styles (and possibly more effective) than private litigants and courts. Kagan very rightly anticipated that adversarial legalism would encounter resistance from national legal cultures and political 
structures but this analysis suggests that national traditions run even deeper: they undercut one of the critical sources of adversarial legalism, suggesting that it never had a fighting change to being with.

The drafting of the first EU directive on data protection is one example of how member states stymied European Commission attempts to improve litigation rights for privacy violations (Bignami 2011, p.438). The best illustration to date of legislative resistance, however, is the ongoing effort to introduce a class action for mass consumer torts in the EU. In the consumer protection area, the Commission has articulated what Christopher Hodges (2014, pp.69-70) calls a three-pillar policy of alternative dispute resolution, enhanced authority for consumer protection agencies, and collective redress to obtain compensation in the courts for consumer harms. To date, however, progress has been mostly been achieved on alternative dispute resolution and administrative enforcement, while collective redress has lagged behind. The only concrete action that has been produced in over five years of institutional debate is a Commission Recommendation adopted in June 2013 exhorting the member states to introduce some form of collective redress mechanism, and a fairly weak one at that, which repudiates many of the key elements of the American system. One of the reasons for this lack of legislative action is continued opposition from the majority of member states in the Council, coupled with what Kagan called the "inherent reflexiveness of human political and legal systems," namely the express desire articulated by both the European Parliament and the European Commission to avoid the pathologies of the American experience with class action litigation (Hodges 2014, p.83). The result is that the current consumer protection regime hews closely to the regulatory style of cooperative legalism: a significant role for public, administrative enforcement, widespread resort to alternative dispute settlement through 
the traditional informal institutions of ombudsmen and neo-corporatist bodies, as well as newer market-based institutions, and relatively little litigation (id. at 81).

The third correction suggested by some of the recent empirical work relates to the particularities of the EU legislative process described above. The importance of national regulatory templates for legislative outcomes points not only to the EU's intrinsic hostility to adversarial legalism but also suggests that EU legislation should be conceptualized somewhat differently from US legislation — as a set of compromises between national regulatory models with elements of adversarial legalism inserted, if at all, on the fringes. If this is the case, then it might be more appropriate to conceive of the legalistic elements of EU regulation as a reflection of, or at least consistent with, the regulatory styles of a certain subset of powerful member states, which require change in the direction of adversarial legalism in other, but by no means not all, member states. In other words, the degree of transformation of regulatory styles may vary significantly by member state, and the transformations that do occur may reflect not the emergence of a novel, adversarial and legalistic mode of regulation, but rather convergence on a dominant, European style.

To again illustrate with data privacy, among the four countries included in my study, the UK system began as the most informal one, due to a combination of the traditional UK policy style and a foot-dragging approach to the substantive issue of privacy: in the 1980s, the administrative authority responsible for data protection had very few regulatory and enforcement powers and individuals were given virtually no legal rights to sue in the courts. Following the passage of the EU directive, which was largely a hybrid of the French and German models, the UK system was transformed more thoroughly in the direction of adversarial legalism than any of the others in the study. The data protection authority acquired rulemaking powers for the first time and obtained a 
host of new enforcement tools, including the power to impose stiff administrative fines. In addition, a general right of action was added to the British privacy legislation and therefore individuals became entitled to sue in court for any type of privacy violation. The institutional practices of both the data protection authority and the courts reflected these legal changes.

Other research suggests that the Dutch system as a whole is vulnerable to change because of its extremely informal and pragmatic traditional regulatory style, which has made it an outlier even among European states. For instance, in their study on regulatory enforcement of the EU packaging waste directive in the Netherlands and Germany, Bastings and her co-authors show that the German system, which was reflected in the directive, remained stable and legalistic, while the previously "passive" Dutch style morphed into a legalistic style (Bastings et al. 2014). More generally, Van Waarden and Hildebrand have documented how the Netherlands in the 1970s represented the informal and consensual extreme of the spectrum, especially when compared to countries like Germany and Austria, and how it has since experienced a dramatic rate of growth in lawyers, legal insurance, administrative litigation, and civil litigation, so that it has largely caught up with its neighbors, albeit with distinctively Dutch neo-corporatist elements (van Waarden and Hildebrand 2009).

There is also evidence that for their own, distinct national reasons, certain member states may be more litigation friendly than others. A recent study on the compensation of asbestos victims showed that while the courts played absolutely no role in Belgium, in the UK there were significant levels of personal injury litigation, and in Italy victims sometimes obtained compensation for damages in criminal prosecutions (Boggio 2013). Similarly, in his otherwise quite muted assessment of how collective redress procedures have been and will be used in national 
jurisdictions, Hodges (2014, p.83) singles out the UK and Italy, together with Poland and, for settlements, the Netherlands as potential "hot spots" for consumer litigation.

In sum, although market liberalization and Europeanization have certainly altered national regulatory styles, they have done so more by enhancing deterrence-oriented enforcement of rules by administrative authorities than by increasing contestation in the administrative process or through the courts. While, as suggested by some of Kelemen's analysis, litigation may become more pervasive in domains such as competition law and corporate law, where the financial stakes are high and the impact of market liberalization is particularly significant, it is unlikely to emerge as the dominant force in European regulatory governance. Among the many contributions of Kagan's scholarship, his comparative frame has pushed others to grapple with the question of what is intrinsic to regulation in liberal markets and fragmented polities - undoubtedly global trends that impact not only the EU but jurisdictions throughout the world-and what is exceptional to regulation in the US. My own view of the evidence so far is that a certain degree of legalization, largely enforced by administrative authorities, is inevitable but that the pervasive contestation of regulatory policymaking characteristic of the US is the product of a distinctive historical experience with the law and politics of the regulatory state.

\section{Conclusion}

The debate provoked by Kagan's comparative insights has by no means been settled. It is possible, however, to identify a number of areas of consensus as to the nature of regulatory change in Europe. First, it is fairly clear that the increasingly dense set of rules coming from Brussels is being applied by special-purpose national regulatory authorities that have acquired new 
enforcement powers and that have moved towards a more legalistic and punitive style of regulatory enforcement. In doing so, these agencies have experienced significant proceduralization of their enforcement activities: administrative bodies like competition authorities, banking regulators, and data protection agencies have had to create internal divisions responsible for conducting adversarial proceedings that can potentially result in heavy-duty fines and other forms of administrative sanctions and that can be, and often are, challenged in court. Second, in some policy areas, and in some countries, litigation invoking the rights and duties of regulatory statutes has become more prominent. This is the case for policy sectors like competition law and securities regulation where liberalization has had a direct and profound impact on the organization of markets (and market actors with the financial incentives to litigate regulatory claims). This is also the case for countries like the Netherlands, which were previously extremely informal and consensual even by European standards, and countries like Italy, which for distinct domestic reasons have experienced a rise in regulatory litigation.

Of course, we, and the many others engaged in this area of inquiry, also differ in our assessment of the current state of affairs and the likely future trajectory of European regulation. The main point of difference concerns the role of rights and litigation in shaping regulation across the policymaking cycle (from general norms to enforcement of those norms in specific cases) and the policymaking spectrum (across all policy areas). While Eurolegalism takes the view that litigants and courts have already become and will continue to become major players across a wide range of policy areas, cooperative legalism sees the balance of power as remaining in the hands of administrative authorities, especially at the rulemaking phase and in areas involving diffuse interest such as consumers and the environment. Even here, as the labels suggest, there is overlap, since both acknowledge that national institutions and legal traditions constitute obstacles to the 
diffusion of adversarial legalism. In Kelemen's assessment, however, national traditions are a stumbling block that stands in the way of the advance of adversarial legalism. In Bignami's assessment, on the other hand, national traditions operate as a central element of regulating a liberalized and fragmented policy space. In a number of sectors, European lawmakers have adapted their existing (non-adversarial) legal toolkit to the new realities of European integration and they are likely to continue to do so going forward, significantly reducing the likelihood that adversarial administrative proceedings and court litigation will come to serve as the dominant mode of policy implementation in Europe.

Settling this debate outlined above will require careful studies of specific policy areas, involving accurate quantitative measures of regulatory litigation and covering a wide range of countries. It is an issue of importance not only for understanding the evolution of regulation in Europe, but also a host of other regions across the globe in which the twin phenomena of the regulatory state and the empowerment of transnational and international bodies are transforming the status quo. At stake are the types of government institutions and public and private professionals that will be empowered to make the resource- distributing and market-stabilizing policy decisions of the regulatory state, with all of the consequences so vividly revealed by Kagan. The difference, put in the starkest terms, is between specialized bureaucracies, on the one hand, and generalist judges and partisan litigators, on the other hand. Which is preferable depends to some extent on how close historically and geographically situated government institutions come to our ideal types of bureaucracies and courts. It also depends on how convincing one finds the normative dimension of Kagan's work.

Another question for further research is the relationship between the increasing legalism of European regulation and informal and flexible modes of regulatory governance. At the same time 
as Kelemen was documenting the rise of Eurolegalism, a number of other scholars were focusing on the increasing popularity in the European Union of "new modes of governance," namely discretionary forms of regulation that allow administrators considerable flexibility in how to interpret regulatory norms and that entrust the regulated parties with significant responsibility for implementing those norms. In cooperative legalism, as illustrated by the data privacy and consumer protection cases, the two forms of regulatory governance-legalistic and selfregulatory-co-exist. There is no doubt, however, that this is a somewhat paradoxical development: top-down agency enforcement and cooperative public-private problem-solving are generally pitted as alternative, not complementary, regulatory techniques. Public enforcement implies fixed legal duties with which market actors are asked to comply whereas self-regulation requires flexible, general public norms that are supplemented through private-sector initiatives. In response to this puzzle, Kelemen has argued that new modes of governance are a "red herring." He contends that they constitute peripheral experiments in governance that have been much discussed by academics but that have had little impact in practice. He argues that attention to these experiments in new governance detract attention from the more pervasive shift to more legalistic regulation-Eurolegalism--across the European policy space (Idema and Kelemen 2006). This certainly is one possibility, but there are others too: some of the research undertaken on efforts to introduce flexible regulation in the American context suggests that hard and soft governance can interact in productive ways (Short and Toffel 2010), while the literature on institutional change highlights the possibility that old forms of European self-regulation may be retooled without being entirely abandoned (Streeck and Thelen 2006). Like adversarial litigation, the question of how hard and soft forms of regulation interact over time will require careful case studies, the results of 
which have implications not only for Europe but for the development of the regulatory state in a number of other regional settings.

The vibrancy of this ongoing debate is a testament to Kagan's influence. Einstein (1938) once said, "The formulation of a problem is often more essential than its solution, which may be merely a matter of mathematical or experimental skill. To raise new questions, new problems, to regard old problems from a new angle, requires creative imagination and marks real advances in science." Throughout his career, Kagan has shown a remarkable knack for asking the right questions--often the vital questions about law and politics others had not thought to ask. His own work has gone a long way to answering these questions, and he has inspired hundreds of others to take up the questions he poses. This has certainly been the case in the study of European regulatory styles. By posing a trenchant question others had not thought to ask, "Should Europe worry about adversarial legalism?" Kagan triggered a vibrant debate and inspired a wealth of research that continues to transform our understanding of European regulatory styles and of the impact of the EU on national regulation.

\section{References}

D. Baharvar, D. (2006-2007). Adversarial Legalism as China's Primary External Model of Legality: What does it mean for China's future? 2 Chinese Law \& Policy Review 65.

Bastings, L., E. Mastenbroek and E. Versluis. (2014). The other face of Eurolegalism: International convergence on packaging waste enforcement styles in the European Union, Paper prepared for panel "in search of coherence in the implementation of EU policies", 
ECPR Standing Group on Regulatory Governance, $5^{\text {th }}$ Biennial Conference, Barcelona, 25-27 June 2014.

Bellantuono, G. (2014). The Regulatory Governance of Public and Private Enforcement, paper prepared for ECPR Standing Group on Regulatory Governance Biennial Conference, IBEI, Barcelona, June 25-27, 2014.

Bignami, F. (2011). Cooperative Legalism and the Non-Americanization of European Regulatory Styles: The Case of Data Privacy, 59 American Journal of Comparative Law 411-61.

Boggio, Andrea. (2013). Compensating Asbestos Victims. Farnham: Ashgate.

Börzel, T. (2002). Pace-Setting, Foot-Dragging, and Fence Sitting, 40 Journal of Common Market Studies 193-214.

Cioffi, J. (2009). Adversarialism versus legalism: Juridification and litigation in corporate governance reform, 3 Regulation \& Governance 235-58.

Einstein, A. (1938). The Evolution of Physics: The Growth of Ideas from Early Concepts to Relativity and Quanta. New York: Simon \& Schuster.

Epstein, D. and S. O’Halloran (1999). Delegating Powers: A Transaction Cost Politics Approach to Policy Making Under Separate Powers. Cambridge: Cambridge University Press.

Faur, M. et al. (2008). Enforcement Practices for Breaches of Consumer Protection Legislation, 20 Loyola Consumer Law Review 361.

Ginsburg, T. (2008). Judicialization of Administrative Governance: Causes, consequences and limits," 3 National Taiwan University Law Review 1. 
Hartnell, H. (2002). EUstitia: Institutionalizing Justice in the European Union 23 Northwestern Journal of International Law and Business 65-138 (2002)

Hodges, C. (2007). Europeanization of Civil Justice: Trends and Issues 26 Civil Justice Quarterly 96-123.

----. (2014). Collective Redress: A Breakthrough or a Damp Sqibb, 37 Journal of Consumer Policy, 67-89.

Idema T. and R. D. Kelemen. (2006). New Modes of Governance, the Open Method of Coordination and Other Fashionable Red Herring, 7 Perspectives on European Politics and Society 108-123.

Johnson, D. (2003). American Law in Japanese Perspective, 28 Law \& Social Inquiry 771.

Kagan, R. A. (1997). Should Europe Worry About Adversarial Legalism? 17 Oxford Journal of Legal Studies 165-183 (1997).

----. (2007). Globalization and legal change: The "Americanization" of European Law? 1 Regulation and Governance 99-120.

Kelemen, R. D. (2006). Suing for Europe: Adversarial Legalism and European Governance, 39 Comparative Political Studies 101-127.

----. (2008). The Americanisation of European law? Adversarial legalism à la européenne, 7 European Political Science 32-42.

----. (2011). Eurolegalism: The Transformation of Law and Regulation in the European Union. Cambridge: Harvard University Press.

----. (2012). Eurolegalism and Democracy, 50 Journal of Common Market Studies 55-71. 
----. (2013). Eurolegalism and the European Legal Field, In Bruno de Witte and Antoine Vauchez (eds.), Lawyering in Europe. Hart Publishing, pp. 243-258.

Kelemen, R.D. and E. Sibbitt, 'The Americanization of Japanese Law" 23 Univ. Penn J. of Int. Econ. Law 269 (2002).

----. (2004). The globalization of American law 58 International Organization 103-36.

Mabbett, D. (2011). A Rights Revolution in Europe? Regulatory and Judicial Approaches to Nondiscrimination in Insurance, LEQS Paper No. 38 (May 30, 2011). Available at $\underline{\text { http://ssrn.com }}$

Maher, I. (2000). Juridification, Modification and Sanction in UK Competition Law, 63 Modern Law Review 544-569.

Meyerstein, A. (2013). Global Adversarial Legalism: The Private Regulation of FDI as a Species of Global Administrative Law, The Internationalization of Public Contracts, M. Audit \& S. Schill (eds.), forthcoming. Available at https://works.bepress.com/ariel_meyerstein/12/

Nadal, C. (2008). Pursuing Substantive Environmental Justice: The Aarhus Convention as a 'Pillar' of Empowerment, 10 Environmental Law Review 28.

Nelken, D. (2003). Beyond Compare? Criticizing "The American Way of Law," 28 Law \& Social Inquiry 799.

Rehder, B. (2009). "Adversarial legalism" in the German system of industrial relations? 3 Regulation \& Governance 217-34. 
Short J. and M. W. Toffel. (2010). Making Self-Regulation More than Merely Symbolic: The Critical Role of the Legal Environment, 55 Administrative Science Quarterly 361.

Streeck W. \& K. Thelen (2006). Introduction: Institutional Change in Advanced Political Economies. In Beyond Continuity: Institutional Change in Advanced Political Economies, W. Streeck \& K. Thelen eds. Oxford University Press, pp. 1-39.

Thatcher, M. (2007). Internationalisation and Economic Institutions: Comparing European Experiences Oxford University Press, pp. 168-98.

Van Cleynenbreugel, P. (2014). Effectiveness through fairness? 'Due process' as institutional precondition for effective decentralised EU competition law enforcement, Paper prepared for $9^{\text {th }}$ ASCOLA Conference Warsaw 2014 on Procedural fairness in competition proceedings, 26-28 June 14.

Van Waarden, F. (2009). Power to the legal professionals: Is there an Americanization of European law? 3 Regulation \& Governance 197-216.

Van Waarden, F. and Y. Hildebrand (2009). From corporatism to lawyocracy? On liberalization and juridification, 3 Regulation \& Governance 259-286.

S Vogel. (1996). Freer Markets, More Rules: Regulatory Reform in Advanced Industrialized Countries. Ithaca, Cornell University Press. 